\title{
Colonial sugar production in the Spanish Philippines: Calamba and Negros compared
}

\author{
Filomeno V. Aguilar Jr.
}

\begin{abstract}
This article presents two modes of export-oriented sugar hacienda production in the late-nineteenth-century Spanish Philippines. The Hacienda de Calamba epitomised a large-scale estate under a religious corporation; it was an enclave economy reliant on local capital and technology. In contrast, Negros showcased a range of haciendas of varying sizes in a frontier setting involving different ethnicities and supported by capital and technology mediated directly by foreign merchant houses. In both locations sugar planters opposed the colonial state, but whereas leaseholders in Calamba, led by Rizal's family, became intentionally political in their resistance, in Negros planters engaged in a persistent and calibrated evasion of the state.
\end{abstract}

In his essay, 'Sobre la indolencia de los filipinos', which was serialised in La Solidaridad in 1890, José Rizal bewailed the fact that working hard in the Spanish Philippines made no sense because the rich person was exposed to all kinds of vexations: 'el rico en la tierra se expone a todos las vejaciones, a todas las molestias'. ${ }^{1}$ Spanish colonial authorities could easily harass the rich man, appoint him village chief and in that position coerce him to make donations that depleted his wealth, and even deport him should an uprising occur. With all these disincentives, he asked - without distinguishing between landholder and peasant labourer, or any other class position for that matter - who would bother to work, engage in economic pursuits, and accumulate wealth?

Filomeno V. Aguilar Jr. is a Professor in the Department of History, Ateneo de Manila University. Correspondence in connection with this article should be addressed to: fvaguilar@ateneo.edu. This is a revised version of a paper presented at the conference, 'Coexistencia e Interacción entre Comunidades en Las Filipinas del Siglo XIX', Instituto de Historia, Consejo Superior de Investigaciones Históricas (CSIC), Madrid, 4-6 Nov. 2015. Many thanks to Lola Elizalde and Xavier Heutz de Lemps for the invitation to participate in this conference. Many thanks to Leloy Claudio, Carol Hau, Mike Pante, and the CSIC conference participants, particularly William Clarence-Smith, Mike Cullinane, and Al McCoy, for stimulating comments, questions, and suggestions that have vastly improved this article. I also thank the referees for their valuable feedback on an earlier version. This is the last of my papers that I had the distinct privilege of having Ben Anderson read; despite his failing health, he gave me pointed comments and precious time. The remaining errors are my sole responsibility.

1 'The rich on earth are exposed to all kinds of trouble, to all kinds of molestations'. José Rizal, 'Sobre la indolencia de los filipinos / On the indolence of the Filipinos', La Solidaridad, vol. 2: 1890, trans. Guadalupe Fores-Ganzon (Pasig City: Fundación Santiago, 1996), p. 392. 
To emphasise the debilitating effects of Spanish colonial rule that fostered and magnified indolence, Rizal recalled times past when natives were discouraged from pursuing agriculture, but he also zeroed in on the late nineteenth century:

El estar las mejoras haciendas, los mejores terrenos de algunas provincias, aquellos que por sus fáciles medios de comunicación son mas ventajosos que otros, en manos de las corporaciones religiosas cuyo desiderátum es la ignorancia y un estado de semi miseria del indio, para continuar gobernándolo y hacerse necesario a su desgraciada existencia, es una de las causas del por que muchos pueblos no progresan a pesar de los esfuerzos de sus habitantes. $^{2}$

[The fact that the best estates, the best tracts of land in some provinces, those that from their easy means of communication are more profitable than others, are in the hands of the religious corporations, whose desideratum is the ignorance and a condition of semidestitution of the native so that they may continue to govern him and make themselves necessary to his wretched existence, is one of the reasons why many towns do not progress in spite of the efforts of the inhabitants.]

Rizal went on to say that the Spanish friars' argument - that 'if these estates were prospering, it was because they were under their care' - was deceptive and it maligned the native as indolent. ${ }^{3}$ To prove that agriculture could prosper even without friar involvement, Rizal argued that the friar haciendas of Bauan and Lian were inferior to Taal, Balayan, and Lipa, all in Batangas province, because the latter were 'cultivated entirely by the natives without monkish interference whatsoever'. ${ }^{4}$

In writing about the disincentives to wealth creation, Rizal was obviously thinking about the Hacienda de Calamba in Laguna province and the troubles that his family - among the largest leaseholders of sugar lands in Calamba - started to experience in the 1880s. The troubles would culminate in the banishment of Rizal's family from the Dominican hacienda in 1891.

But in stressing the disincentives to economic enterprise and bemoaning friar control of the best haciendas, Rizal was silent about agricultural production in other parts of the country. Since the 1810 s ships that called in at the port of Manila bought sugar, the principal export commodity that beginning in the $1820 \mathrm{~s}$ the earliest merchant houses shipped to overseas markets. ${ }^{5}$ By 1845 sugar was being produced in nine provinces, foremost of which were Pampanga, Cebu, and Bulacan. ${ }^{6}$ By midcentury Robert MacMicking highlighted the sugar from Pampanga, Pangasinan, Cebu, and Laguna (known for 'Taal sugar'), but sugar from Iloilo was

2 Ibid., pp. 394, 396.

3 Ibid., pp. 396, 397.

4 Ibid., pp. 396, 399.

5 Benito Legarda Jr., After the galleons: Foreign trade, economic exchange and entrepreneurship in the nineteenth-century Philippines (Quezon City: Ateneo de Manila University Press, 1999), pp. 236-43, 280.

6 Data for 1845 showed total sugar production in the Spanish Philippines at 265,045 pilones (one pilon averaging roughly 50 kilos), distributed as follows: Pampanga (94,587 pilones; 35.7 per cent); Cebu (63,582 pilones; 24.0 per cent); Bulacan (51,930 pilones; 19.6 per cent); Iloilo (15,310 pilones; 5.8 per cent); Bataan (13,571 pilones; 5.1 per cent); Pangasinan (10,811 pilones; 4.1 per cent); Laguna (7,029 pilones; 2.6 per cent); Tondo (6,019 pilones; 2.3 per cent); and Cavite (2,206 pilones, 0.8 per cent). Philippine sugar production remained trifling by international standards, and certainly paled in comparison to Cuba; this state of affairs prompted Madrid to make an official inquiry. Filomeno Aguilar Jr., Clash 
'sometimes, though rarely, distinguished as a separate quality'. In the late $1850 \mathrm{~s}$ Negros, whose sugar was exported via the port of Iloilo, joined this club of major sugar producers.

Was Rizal unaware of the considerable wealth that was being generated from sugar production on Negros Island, which by the 1860s Spanish colonial officials had dubbed the Emporium of Wealth in the Visayas? Even more intriguing was the fact that in his essay on indolence Rizal nowhere mentioned the prosperity of sugarcane growers in Pampanga, just north of Calamba. In Europe he befriended some youths from that province, particularly the monied José Alejandrino whom he persuaded to leave Madrid to study engineering in Ghent, where the two friends shared a rented room and where Rizal wrote and published El filibusterismo in $1891 .{ }^{8}$ If not for pure polemics, was Rizal unwilling to write about something he had not seen personally, given the fact that, despite his wide international travels, in the Philippines he had never gone beyond the Tagalog region, except when he was deported to Dapitan in Zamboanga? How did he come to portray the character of Capitan Tiago in Noli me tangere as not only one of the most affluent property owners in Binondo, but also as owning large haciendas in Pampanga and Laguna? When it came to his essay on indolence, to counter the argument that friars were indispensable to economic advancement, Rizal chose to hold up non-friar haciendas in other parts of Batangas, his sights seemingly unable to extend beyond his corner of the Tagalog region.

This article, however, is not so much an explication of the agrarian unrest in Calamba or even of Rizal's argument in his essay on indolence as it is an attempt to stand in the gap in that essay. It seeks to shed light on agricultural activities that thrived outside of the friar estates. Beginning with Calamba, the article explores the spatial variations in agricultural conditions through a portrayal of two modes of hacienda production involving the same produce - sugar - in the late-nineteenthcentury Spanish Philippines. The different localities ${ }^{9}$ of sugar production can be placed in a continuum, with Calamba and Negros serving as polar opposites. ${ }^{10}$

of spirits: The history of power and sugar planter hegemony on a Visayan island (Honolulu: University of Hawai'i Press; Quezon City: Ateneo de Manila University Press, 1998), pp. 82-6, 90-92, 242.

7 Robert MacMicking, Recollections of Manilla and the Philippines, during 1848, 1849, and 1850 (London: Richard Bentley, 1851), pp. 281, 285.

8 José Alejandrino, The price of freedom: Episodes and anecdotes of our struggles for freedom, trans. Jose M. Alejandrino (Manila: The author, 1949), pp. 1-14; John Larkin, The Pampangans: Colonial society in a Philippine province (Berkeley: University of California Press, 1972), pp. 94-5; John Schumacher, The Propaganda Movement: 1880-1895; The creators of a Filipino consciousness, the makers of the revolution (Quezon City: Ateneo de Manila University Press, 1997), pp. 236, 272.

9 The localities or units of analysis do not have to be formal administrative units. According to Michael Cullinane (email to the author, 15 Nov. 2015), some parts of Cebu Island resembled Calamba while other parts resonated with Negros. However, to date no systematic analysis of sugar production in Cebu has been written, although many areas of this history are covered in: Bruce Fenner, Cebu under the Spanish flag, 1521-1896: An economic-social history (Cebu City: San Carlos, 1985). That the province of Bulacan was an important sugar producer in the middle of the nineteenth century is hardly mentioned even in local histories. In Iloilo's case, sugar production has been almost completely overshadowed by Negros sugar, even in the otherwise thorough study of Iloilo City by Alfred McCoy, 'A queen dies slowly: The rise and decline of Iloilo City', in Philippine social history: Global trade and local transformations, ed. Alfred W. McCoy and Ed. C. de Jesus (Quezon City: Ateneo de Manila University Press, 1982), pp. 297-358. 10 In this continuum Pampanga can be placed somewhere between Calamba and Negros. For a comparison of the two major sugar-producing provinces of Pampanga and Negros, see John A. Larkin, Sugar 
The Hacienda de Calamba epitomised a large-scale estate under a single corporate (religious) entity, which was essentially an enclave economy; in contrast, Negros showcased a range of haciendas of varying sizes in a frontier setting where different actors and ethnicities sought to carve a niche. Both places shared the common practice at that time of subdividing large properties into smaller parcels of land cultivated by sharecroppers. However, the Dominican owners of Calamba relied on a sector of wealthy leaseholders (known as inquilinos), generally local Chinese mestizos, ${ }^{11}$ who mobilised a stratum of subtenants on sharecropping arrangements. In Negros the sugar planters (known as hacenderos) comprised a multiethnic immigrant class of landowners most of whom directly hired their own tenants while others employed overseers who supervised the tenantry. Sociologically, Negros evolved a distinctive plural society, quite unlike the conventional colonial social formation in Calamba.

With sugar from both localities destined for export, both places were linked with global capitalism, but their articulation differed in significant ways. In Calamba Chinese mestizo lessees relied on their own capital or on Chinese moneylenders and middlemen who brought the goods to foreign merchants in Manila. In contrast, the sugar haciendas in Negros relied on loans and capital advances that were sourced directly from foreign merchant houses based in Iloilo on the nearby island of Panay. The direct engagement of the foreign merchants in Iloilo as financiers of Negros's sugar economy spelled a major difference, especially in terms of a higher level of sugar milling technology compared with what prevailed in Calamba.

Rizal's essay on indolence hinted at discontent in Calamba. In fact both locations generated resistance and defiance on the part of sugar planters, but their actions were embedded in divergent colonial state dynamics. Intentionally political, those in Calamba targeted a religious order that Spanish authorities ultimately propped up in defence of the colonial state. Those in Negros had no friar order for an antagonist and no political agenda; they engaged the colonial state whenever it was to their advantage, but simultaneously and rather systematically undermined a state that, despite attempts at centralisation, was weighed down by many contradictions. ${ }^{12}$

and the origins of modern Philippine society (Berkeley: University of California Press, 1993). In this article I rely on the comparative frame of Calamba and Negros, in part because Calamba, although highly significant for nationalist historiography, has seldom been seen in comparative perspective and because, for practical reasons, adequate information exists for both Calamba and Negros to enable the analysis pursued here. In fact, there is limited information on many aspects of sugar production in Pampanga during this period (see Larkin, The Pampangans, pp. 63-102; Larkin, Sugar, pp. 82-99); but pertinent information, whenever available, is brought into the discussion.

11 In this article the term 'Chinese mestizo' is primarily the historian's. In Rizal's case, his grandfather had taken advantage of a scheme that allowed the family's official transfer from the tribute list of Chinese mestizos to that of the naturales. In 1884, the colonial government's shift to a modern taxation system formally abolished the tribute categories that had distinguished the Chinese mestizo from the naturales, although in larger urban areas the colonial governance mechanism of having separate gremios or corporate councils for naturales and Chinese mestizos, especially for civil and ceremonial affairs, was not immediately discontinued.

12 The Spanish colonial state has been commonly described (including in my own earlier work, Clash of spirits) as weak. However, this description fails to explain the longevity of Spanish rule (over three centuries); it also fails to explain complex events in the late nineteenth century such as the incorporation of the one-time maritime power, the Sulu Sultanate. 
Given the archipelagic character of Las Islas Filipinas, the mountain redoubts provided an escape from the colonial state, but so did sparsely populated islands. Negros was such an island prior to the veritable invasion that occurred after the late 1850s with the rise of the sugar economy. In the frontier setting of Negros, the sugar haciendas and their mix of owners, overseers, and farm hands arose in response to the market. Deploying capital brokered by foreign merchant houses, these haciendas managed to put the state at arm's length, made all the more adventuresome by the Recollect friars who were partners of sugar planters in keeping the state at bay. Set apart from Calamba, which like other monastic estates epitomised the state, the sugar economy of Negros thrived in the late nineteenth century in the shadow of the central state.

\section{Hacienda de Calamba}

Unlike the sugar haciendas of Negros most of which trace their beginnings to the second half of the nineteenth century, the Hacienda de Calamba had a longer and older history. Located $53 \mathrm{~km}$ south of Manila, Calamba's fertile lands extended westward from the shore of Laguna de Bay and had housed several early Spanish estates. As Dennis Roth has shown, the ownership of Hacienda de Calamba passed from one lay Spaniard to another until in 1759 'its destitute owner turned over the hacienda to the Jesuits in exchange for the right to room and board in their monastery for the rest of his life'. ${ }^{13}$ When the Jesuits were expelled from the Philippines in 1768, the government confiscated the property. An inventory indicated the bulk of the estate had remained uncultivated. Of the hacienda's total area of close to 15,000 ha, less than 300 ha (or 2 per cent) had been planted with rice or sugarcane. ${ }^{14}$ The government succeeded in selling the estate to a lay Spaniard in 1803; when the heavily indebted owner died in 1833, the Dominicans finally acquired the hacienda. In 1843 an Englishman, with the backing of the governor-general, offered to buy the estate, but the Dominicans rejected the offer. ${ }^{15}$

Under these circumstances, the Hacienda de Calamba had been bypassed by the commercial revolution that, in tandem with population growth, had led to the dramatic need for cultivable land on the friar estates and its peripheries; by the same token, Calamba was unaffected by the 1745 Tagalog revolts that these transformations in commerce and demography had precipitated. ${ }^{16}$ By the end of the eighteenth century the estate had remained largely uncultivated. It is not clear when cultivation expanded in earnest, but Roth states that by the middle of the nineteenth century

the scale of Calamba's economy had grown far beyond its former restricted limits. Hundreds of hectares of land had been cleared and many new families had migrated to the hacienda from neighbouring towns. Among them were the ancestors of José Rizal. ${ }^{17}$

13 Dennis M. Roth, The friar estates of the Philippines (Albuquerque: University of New Mexico Press, 1977), p. 16.

14 Ibid.

15 Ibid., p. 152.

16 Roth, The friar estates; Fernando Palanco, 'The Tagalog revolts of 1745 according to Spanish primary sources', Philippine Studies 58, 1-2 (2010): 45-77.

17 Roth, The friar estates, p. 16. 
To be precise, it was Rizal's father, Francisco Mercado, who moved to Calamba from Biñan, where Rizal's paternal grandfather had thrice been gobernadorcillo or town mayor. ${ }^{18}$ The move to Calamba must have transpired not earlier than the late 1830s, when Francisco was of age and the estate was already in the hands of Dominicans from whom the Rizal family leased land.

If Calamba's expansion of cultivated area and increase in population occurred just before or around the middle of the century, then it would have preceded the rise of sugar haciendas on Negros Island by one or two decades. Calamba by the 1850s was already a thriving economy, with much of its dynamism brought by migrants, while Negros (its capital Bacolod located about $650 \mathrm{~km}$ south of Manila) was still largely a backwater, with a very sparse population of about 100,000 - a figure that would rise four-and-a-half times by the end of the century. ${ }^{19}$

In 1848 the Recollects acquired Negros from the secular clergy and the island became their mission field. Although they possessed estates elsewhere, such as the Hacienda de Imus in Cavite, the Recollects did not acquire any monastic estate in Negros, probably due to the island's underpopulated state when they first arrived there. However, many Recollect priests engaged in 'development' work, building basic infrastructure such as roads and potable water facilities. ${ }^{20}$ One particular priest, Fernando Cuenca, parish priest of Minuluan (known as Talisay today), later became heavily involved in stimulating and supporting the cultivation of sugarcane, including on his own private properties. ${ }^{21}$

\section{Land and sugar in Negros and Calamba}

By the 1850s Negros had only four major, mostly immigrant, sugar hacenderos: ${ }^{22}$ the creole Agustin Montilla in Bago and the Basque Eusebio Ruiz de Luzuriaga in Bacolod; the Frenchman Ives Leopold de Germain Gaston in Silay (who in the late 1830s had supervised the planting of sugarcane and the construction of a steampowered mill on the estate of the creole Domingo Roxas in Calatagan, Batangas); ${ }^{23}$ and someone called Tia Sipa in Minuluan. ${ }^{24}$ In the early 1850 s these four sugar planters produced no more than 3,000 pilones of sugar (out of a total Philippine sugar production of 265,045 pilones). At a time of rising world sugar prices in the wake of the Crimean War, the presence of Nicholas Loney as British vice-consul in Iloilo a year after the colonial government opened up its provincial port to world trade

18 Leon Ma. Guerrero, The first Filipino: A biography of José Rizal, new ed. (Manila: Guerrero, 2010 [1961]), p. 20.

19 Aguilar, Clash of spirits, p. 127.

20 Ibid., pp. 158-9. See further Angel Martinez Cuesta, History of Negros, trans. Alfonso Felix Jr. and Sor Caritas Sevilla (Manila: Historical Conservation Society, 1980).

21 Aguilar, Clash of spirits, p. 159.

22 Robustiano Echaúz, Apuntes de la isla de Negros (Manila: Chofre y Cia, 1894), pp. 22-3.

23 Carlos Quirino, The history of the Philippine sugar industry (Manila: Kalayaan, 1974), pp. 19-20.

24 The terms 'creole' and 'peninsular' as applied to Spanish individuals in this article are largely reputational. In census data presented later, the terms are census categories and therefore dependent on the definition followed by the enumerators. Nick Joaquin argues for the blurred distinction between creole and Spanish mestizo: 'Up to around midway of the 19th century ... the Philippine Creoles had no such scruples about blood purity and were distinguished as a class apart, as "Filipinos," not so much by the amount of Spanish blood in their veins as by their culture, position and wealth.' Nick Joaquin, A question of heroes (Mandaluyong City: Anvil, 2005), p. 72. 
in 1855 would serve as the greatest stimulus to sugar production in the region, ${ }^{25}$ a story that has been retold a number of times. Sugar production on Negros Island would begin to rise from the late 1850s all through the 1860s, until the end of the century.

In Iloilo on Panay Island there were some small sugar haciendas by the early $1850 \mathrm{~s}^{26}$ It is noteworthy that the expansive areas that were already devoted to rice cultivation in Iloilo were not converted to sugar. ${ }^{27}$ This fact suggests that landowners who might have preferred a nonfood crop like sugarcane could not brush aside the peasantry's need for subsistence and that sizeable gains were already being obtained from the sale of surplus rice to parts of the Spanish Philippines that had concentrated on hemp and coconut. ${ }^{28}$ Rather than in Iloilo, new sugar haciendas were founded on Negros Island, a frontier zone located just across the Guimaras Strait, the distance between Iloilo City and Bacolod City being $43.78 \mathrm{~km}$. In this sense, what transpired in the Visayas differed from the model that at one point Madrid considered: the Cultivation System introduced by the Dutch in Java, where native elites, who had been fully incorporated into the colonial state apparatus, mobilised a forced labour system and utilised communally held land as the state directed. ${ }^{29}$ In Negros as well as in Calamba, the push to produce sugar did not come from the state but from the market. However Pampanga, where sugar production started earlier than in Calamba and Negros, posed an instructive contrast. Whereas it used to be a prime exporter of rice, Pampanga ceased to be so by 1838 , after peasants shifted their crop from rice to sugarcane beginning in the 1820s, with Pampanga people subsequently opening up new land to the north of the Rio Grande to grow more sugarcane. ${ }^{30}$

Negros continued to produce food crops, particularly in a few small towns on the southern portion of the island where peasants almost exclusively grew either rice or corn. On the west coast of the island eight municipalities became virtually monocrop economies, producing an annual total of 549,500 piculs of sugar in the 1880s, representing 63 per cent of the island's aggregate sugar production of 965,100 piculs. ${ }^{31}$ The largest sugar producers were Minuluan, Saravia, and Silay. ${ }^{32}$ However, there were fifteen towns that grew a combination of sugar (totalling 324,000 piculs or 37 per cent of the island's total sugar production) and rice (288,500 cavans or 95 per cent of the island's aggregate rice production). ${ }^{33}$ In these towns, the smallest farms were devoted to rice, while the biggest farms planted sugarcane.

25 Filomeno Aguilar Jr., 'Beyond inevitability: The opening of Philippine provincial ports in 1855', Journal of Southeast Asian Studies 25, 1 (1994): 70-90.

26 Quirino, The history of the Philippine sugar industry, p. 32.

27 The wide alluvial Iloilo Plain has been 'one of the archipelago's historic granaries' (McCoy, 'A queen dies slowly', pp. 298, 300). Today Iloilo is known as the 'rice bowl' of the Western Visayas, with about 132,000 ha under rice cultivation, only 42 per cent of which is irrigated. Iloilo produces a surplus that is shipped to Negros Occidental, Cebu, Leyte, Samar, and some parts of Mindanao. Ireneo Olivares, 'Iloilo', in Why does the Philippines import rice? Meeting the challenges of trade liberalization, ed. David C. Dawe, Piedad F. Moya and Cheryll B. Casiwan (Los Baños: International Rice Research Institute, 2006), p. 119.

28 See Legarda, After the galleons, pp. 169-70.

29 Aguilar, Clash of spirits, p. 83.

30 Larkin, The Pampangans, pp. 66-7.

31 Aguilar, Clash of spirits, pp. 103-4.

32 Ibid., p. 103.

33 Very roughly a cavan when applied to rice was equivalent to $60 \mathrm{~kg}$, but it had a different equivalence for other products. 
There were various schemes for acquiring land in Negros - ranging from outright purchase to leasing, land-grabbing (usurpación), acquiring foreclosed property (embargado), and opening up new land. The sizes of sugar haciendas in Negros varied widely throughout the late nineteenth century. In 1861 recorded land transactions ranged from about 2 ha to at most 60 ha, with the average land sale involving approximately 16 ha. A process of land enlargement and expansion occurred such that by 1875 the largest hacienda that was sold measured 200 ha, the mean size being 35 ha. By 1890 the average area of land that exchanged ownership measured $100.5 \mathrm{ha}^{34}$ The mean area of land sold rose by 118.8 per cent from 1861 to 1875 and by 187.1 per cent from 1875 to 1890 .

Some hacenderos employed various means to acquire enormous tracts of land: Teodoro Benedicto owned over 1,100 ha ${ }^{35}$ while Isidro de la Rama, Teodoro Yulo, and Eugenio Lopez had similar-sized landholdings. ${ }^{36}$ More often than not, however, these properties were not always contiguous and did not constitute one large 'plantation'. Given the dynamics of the land market, hacenderos even bought small farms, which were distinct from and could not be consolidated with the larger properties that they also owned. All these properties had names, probably in imitation of the friar haciendas.

In Minuluan in the early 1890s, the largest property owner was Isidro de la Rama, who owned a total of 1,260 ha distributed into four separate properties: one was 800 ha in size; another, 250; still another, 150; and a fourth one, 60. Other large property owners in Minuluan included Lucio Lacson, who owned two properties that measured 900 ha in aggregate (500 and 400 ha); Aniceto Lacson, who had five properties totalling 441 ha $(400 ; 18 ; 12 ; 7$; and 4 ha); Rosendo Lacson, who had three properties that added up to 303 ha (300; 2; and 1 ha); and Andres Arroyo, who owned two haciendas that amounted to 300 ha (250 and 50 ha). ${ }^{37}$

The size of any one hacienda varied greatly, but no one in Negros owned land on the scale of the Dominicans in Calamba (or other friar estates for that matter). Haciendas owned by commercial companies were of relatively modest proportions. In La Carlota, for instance, in the 1890s Ynchausti y Compañía owned two haciendas, one called Hacienda San Jose measuring 300 ha and another called Hacienda Salamanca measuring 400 ha. ${ }^{38}$

34 Aguilar, p. 115.

35 Ibid., p. 112.

36 Larkin, Sugar, p. 65.

37 'Estadística de los terrenos agrícolas de propiedad particular existentes en este pueblo, Pueblo de Minuluan', Estadística, Negros Occidental, 1896, Part II, Manila, National Archives of the Philippines. Landownership also became extensive in Pampanga, with a great diversity in land sizes. Thirty-seven landowners' wills from 1889 to 1896 bequeathed land ranging from 10 ha to 1,033 ha, with the average computed at 155 ha. The Spaniard Roberto Toledo reportedly owned 3,348 ha (Larkin, The Pampangans, pp. 76, 78). In many cases, however, farm holdings were scattered across the province and not contiguous because many were acquired through the widespread practice of pacto de retroventa (repurchase agreement) that worked following the Tagalog scheme of sanglang-bili, a system of pawning land that was deemed sold when the debtor did not redeem the property at the set time.

38 'Estado del número de habitantes en este pueblo durante el expresado año con expresión de razas'; 'Numero de habitantes con expresión de razas'; 'Estadistica de los terrenos agrícolas de propiedad particular existentes en este pueblo'; 'Estado urbano-agricola-comercial de este pueblo durante el expresado 
While sugarcane predominated in Negros, rice remained the principal crop on the friar estates near Manila. Roth estimated that sugar accounted for no more than 10 per cent of the incomes of all friar orders. ${ }^{39}$ Only the adjoining Dominican estates of Biñan, Santa Rosa, and Calamba - the three largest monastic estates in Laguna province - had significant production of sugar, which would not become extensive until the late nineteenth century. ${ }^{40}$ The growth in sugarcane cultivation was 'most spectacular' in Calamba, ${ }^{41}$ where the inquilinos were 'more dependent on sugar cane than most tenants of other friar estates' ${ }^{42}$ - making Calamba an exceptional sugar-producing friar land and the Dominicans quite enterprising compared with other friar orders in supporting sugar production.

However, unlike the various schemes for acquiring land in Negros, there was only one way to acquire land for sugar cultivation in a friar estate: enter a leasehold contract (inquilinato) with the hacienda owner through the administrador or friar administrator, also known as hacendero. The land was rented out on three-year contracts. ${ }^{43}$ In Calamba land for sugarcane cultivation came from the peripheries, most of which reportedly had been cleared already and devoted to rainfed upland rice. ${ }^{44}$ New lands were also cleared at the cost of the leaseholder rather than the hacienda management. Because of the inquilino's start-up expenses, the rent was suspended for three to four years until the land could be made productive. ${ }^{45}$ In 1890, when Rizal's older brother Paciano was negotiating to lease more land for sugar cultivation, the administrator of the Hacienda de Calamba claimed that abundant land was available; he offered five years of rent-free usage, the prolonged grace period purportedly to encourage a wider sugar cropping area. ${ }^{46}$

Considered one of the largest leaseholders in Calamba, Rizal's family by 1890 rented 66.2644 quiñones (about 382 ha) of sugar land and 1.6952 quiñones (about 9.8 ha) of rice land, based on the official conversion of 5.76 ha per quiñon. ${ }^{47}$ Like everyone else, they rented house lots that for different family members added up to 0.1275 quiñon or 0.7344 ha. ${ }^{48}$ The Rizals' farm holdings were considered huge by Calamba standards and compared favourably with many of the larger haciendas in Negros, enabling Rizal's family to accumulate wealth. But their landholdings did not measure up to the largest properties in Negros. In Calamba sugar planters, such as Rizal's family, were constrained in accessing cultivable land by both the size and administration of the Dominican estate.

año.' Pueblo de La Carlota, 31 de Diciembre 1896. Estadística, Negros Occidental. Part I, National Archives of the Philippines, Manila.

39 Roth, The friar estates, p. 135.

40 Ibid., pp. 123-4.

41 Ibid., p. 135.

42 Ibid., p. 18.

43 Ibid., p. 143.

44 José Arcilla, 'Documents concerning the Calamba deportations of 1891', Philippine Studies 18, 3

(1970): 592.

45 Roth, The friar estates, p. 143.

46 Arcilla, 'Documents', p. 582.

47 Roth, The friar estates, pp. 139, 171.

48 Ibid., p. 171. 
The Hacienda de Calamba's income from sugar increased from a few hundred pesos in the late 1830 s to more than 40,000 pesos in $1895 .{ }^{49}$ Roth's indispensable study shows that the rent for sugar lands, although less than that for rice lands and certainly not onerous in good years, doubled from the middle to the end of the nineteenth century: 'From fifteen pesos for a quiñon of first-class land in the 1840s, it was increased to twenty, then twenty-five, and finally thirty pesos, where it would remain until the revolution.' 50 If for any reason the annual rent could not be paid, the rent for the following year was doubled, which happened in Calamba in 1886 and 1887.. Moreover, 'the specie payments for sugar were at their highest point (before 189496) in 1887 at a time when the country was facing a commercial and agricultural crisis' ${ }^{52}$ It was also the beginning of the rinderpest epidemic, and a few months later the inquilinos' legal battle in Calamba would begin to unfold.

\section{Sharecropping in Calamba and Negros}

Like other friar-owned estates, as Dennis Roth has shown, Calamba had passed from a two-tiered structure consisting of the hacienda management and its tenantcultivators to a three-tiered structure, with an intermediary stratum of tenantleaseholders who were positioned between the hacienda management and the tillers of the soil. ${ }^{53}$ As we have noted, this change occurred relatively late in Calamba compared with other monastic estates. In Calamba the intermediate layer of inquilinos emerged in the first half of the nineteenth century. These lessees subdivided the leased property and entered into sharecropping arrangements with subtenants, peasants known as kasama. One inquilino would have several kasama. In the two-tiered system the hacienda management provided tenants (the original inquilinos) with loans in the form of tools, carabao, and rice as well as the cash to pay hired labourers. ${ }^{54}$ In the three-tiered system this role was assumed by the leaseholder, the new inquilino, who devolved cultivation to several kasama. Friar hacienda management merely collected rent from the leaseholders and was thus removed from its former role of provisioning peasants.

Traditionally the sharecropper, known as kasama in Tagalog, agsa in Negros, casamac in Pampanga, and aparcero in Spanish, enjoyed a considerable degree of autonomy in the labour process. The landowner or lessee who entered into an arrangement with a kasama, usually on a 50-50 sharing of the produce, provided the latter with land as well as cash advances on production, the money often spent on non-farm items; for his part, the share tenant as production partner was responsible for seedlings in the case of rice cultivation, the carabao, and farm implements. ${ }^{55}$ Additionally, in sugar tenancies in Pampanga the landowner supplied the cane cuttings for planting, the use of the sugar mill, and mill hands; while the tenant was

49 Ibid., p. 135. Calamba's rental income from rice similarly rose from 1,595 pesos in 1850 to 9,361 pesos in 1880 and further to 44,842 pesos in 1895 (ibid., p. 136).

50 Ibid., p. 142.

51 Ibid., p. 143.

52 Ibid., p. 141.

53 Roth, The friar estates; Dennis M. Roth, 'Church lands in the agrarian history of the Tagalog region', in McCoy and de Jesus, Philippine social history, pp. 131-53.

54 Roth, The friar estates, p. 85.

55 Aguilar, Clash of spirits, pp. 78-81. 
responsible for planting and harvesting the cane and paying and feeding hired labour. ${ }^{56}$ Somewhat reducing the sharecropper's autonomy, the inquilinos in Calamba did not detach themselves from farm work and acted as mini-administrators of sorts, as Paciano Rizal evinced in directing the work of share tenants and sugar milling. ${ }^{57}$ Unlike rice, sugar necessitated that the inquilino or hacendero or whoever was managing the farm exercised some form of supervision over the many share tenants in any sizeable hacienda, if only to attain a modicum of coordination in the use of the mill without losing too much of the sugar content of the cut cane; the inquilino or hacendero also negotiated with middlemen in selling the sugar.

Akin to Calamba's inquilinos, the Negros hacenderos practiced sharecropping, the system of cultivation that Robustiano Echaúz and others referred to as lo mas corriente, 'the most common'. ${ }^{58}$ Echaúz said it was 'the best, the easiest and the most convenient' method of organising the hacienda. ${ }^{59}$ Loney had also observed that 'on all plantations of any extension there are besides day labourers a number of families or tenants, called acsas' ${ }^{60}$ Thus hacenderos in Negros partitioned their sugar haciendas into farm lots that were cultivated directly by tenants. Much like the inquilinos in Calamba, the Negros sugar planters supplied their sharecroppers with work animals, farm equipment, and cash advances to attract them to remain on the farm. Hacenderos endeavoured to transform these peasants into a loyal workforce through various acts of paternalism, centred on the use of the mill. ${ }^{61}$ Whereas in Pampanga carabaos were the responsibility of the casamac, in Negros (as in Calamba) the hacenderos provided these draft animals to their tenants as an added incentive. The share tenant was responsible for harmonising the labour process with work gangs and day labourers, but hacenderos were keen to ensure that transient cane cutters and other hired workers were available at the time they were needed. ${ }^{62}$ Strong parallels marked the sugar sharecropping practices in Calamba and Negros.

Echauz also reported that some sugar haciendas followed the 'administration' system, with a salaried staff of overseers (encargados) and foremen (cabos) who supervised the work of tenants and day labourers, ${ }^{63}$ echoing the former two-tiered administration system on the friar lands. There is limited corroborating evidence concerning this assertion coming from that period. ${ }^{64}$ Interestingly, in the census data conducted in the late 1890s, a handful of sugar haciendas were noted as administrado,

56 Larkin, The Pampangans, p. 81.

57 Roth, The friar estates, p. 17.

58 Echaúz, Apuntes, p. 43.

59 Ibid., p. 44.

60 Aguilar, Clash of spirits, p. 126.

61 Ibid., pp. 141-6.

62 Ibid., pp. 130-41.

63 Echaúz, Apuntes, p. 56.

64 Larkin cites a 1911 article in Renacimiento Filipino that describes the administration system in Isidro de la Rama's hacienda in Bago, but of the '2,700-hectare estate' only one-third was devoted to sugar. Larkin claims, despite the lack of strong evidence, that the 'owner or employee management of a hacienda of salaried workers' as the 'most common system' in Negros (Larkin, Sugar, p. 76). Similarly, McCoy contrasts the 'Negros plantation' from the 'tenanted sugar plantations of Central Luzon' in that 'Negros haciendas were cultivated by supervised work-gangs paid on a nominal daily wage' - an assertion that is not consistent with the historical evidence (McCoy, 'A queen lies slowly', p. 325). On this and other erroneous historical assertions about Negros, see Filomeno Aguilar Jr., 'The fulcrum of 
specifically in Minuluan (but not elsewhere) where this was noted in relation to a 100-ha hacienda owned by Aguada Lizares; three land parcels (29, 11, and 4 ha) owned Pio Sian; and another three land parcels (71, 58, and 51 ha) owned by Mateo Hernaez. ${ }^{65}$ In the same locality haciendas that were four to five times bigger than 100 ha were not designated as administrado. It is not clear if a hacienda that was administrado necessarily meant it was practising what Echauz called the 'administration' system, but if it did, then the administration system was utilised not in the biggest haciendas but in relatively smaller haciendas. Certainly it was not widely practised, as Echauz himself stated. Census data available in the National Archives of the Philippines also suggest that landowners who owned several haciendas had colonos (colonists), ${ }^{66}$ who probably approximated the leaseholders in Calamba who entered into sharecropping arrangements with their own tenant-cultivators.

Given the difficulties of controlling the labour of peasants in a predominantly subsistence economy, the regimentation of labour in a plantation system would have had to hurdle enormous difficulties, and particularly so because the fledgling sugar planter class in Negros was not hegemonic at this stage. ${ }^{67}$ Not surprisingly, most sugar haciendas, whether managed by the landowner or a colono or an overseer, resorted to sharecropping, which was practised widely in Negros until the shift to capital-intensive centrifugal milling in the 1930s made share tenancy counterproductive because of the need for strictly synchronised planting and feeding of cut cane to the sugar centrals. ${ }^{68}$

\section{Foreign merchant houses and investments}

For our purposes, what is important to emphasise is the divergent effect on investments in sugar milling technology associated with the production system that prevailed in Calamba and Negros. In Calamba Chinese mestizo leaseholders usually entered agriculture with capital generated from commercial and other economic activities, and were thus self-financing. If the capital was insufficient, the inquilinos borrowed money from Chinese moneylenders in Manila (los acaparadores Chinos de Manila), as suggested by the friar administrator of Calamba. ${ }^{69}$ Whether these moneylenders obtained cash from the foreign merchant houses in Manila is not known, but their moneylending activities did assure them that at harvest time they had access to the clayed sugar, the solid cones of sugar produced by boiling the liquid extracted from the cane. The system in Calamba must have hewed closely to the scheme observed by MacMicking at midcentury:

structure-agency: History and sociology of sugar haciendas in colonial Negros', Philippine Sociological Review 61 (2013): 87-122.

65 'Estadistica ... Minuluan', National Archives of the Philippines.

66 Estadística, Negros Occidental, Part I, National Archives of the Philippines. In Puerto Rico members of the sugar planter class were known as colonos; see Juan Giusti-Cordero, 'Compradors or compadres? "Sugar barons" in Negros [the Philippines] and Puerto Rico under American rule', in Sugarlandia revisited: Sugar and colonialism in Asia and the Americas, 1800 to 1940, ed. Ulbe Bosma, Juan Giusti-Cordero, and G. Roger Knight (New York and Oxford: Berghahn, 2007), pp. 177-202.

67 Aguilar, Clash of spirits, pp. 126-55.

68 Ibid., pp. 215-22.

69 Arcilla, 'Documents', p. 582. 
The Chinese or Mestizos who are engaged in the purifying of sugar are the purchasers of these lots, and most of them are in the habit of sending an agent through the country, with orders to buy up as much of such sugar as they require to keep their establishments at work. ${ }^{70}$

The sugars were brought to Manila, processed, and passed on to foreign merchant houses for export overseas. ${ }^{71}$ This scheme of things, in which Calamba fitted, was dependent on the Anglo-Chinese commercial network that generally dominated the colonial economy of the Spanish Philippines.

Foreign merchants as a whole possessed the requisite 'commercial intelligence' to participate in the world market; they 'possessed the expertise, contacts, finances, and facilities to make the sugar trade a success', as John Larkin put it. ${ }^{72}$ Benito Legarda has mapped out the operations of foreign merchant houses, which served as commission agents of European and American firms and at the same time operated as bankers in their role as recipients of local deposits and financiers of rural enterprises. ${ }^{73}$ Foreign merchant houses served as the principal institution that mobilised savings and channelled them to agricultural investments, mainly through advances that 'were made through layers of intermediaries of diverse ethnicity'. ${ }^{74}$

Nonetheless, there is no evidence of these foreign merchants' direct or indirect investments in Calamba. On the whole, the capital invested in Calamba remained limited, merely sustaining sugar production in the way it had been done customarily, with little improvement in sugar milling technology. Made to bear huge risks with no security of tenure over land, the leaseholders understandably were disinclined to make huge investments. Additionally, whereas in Negros most hacenderos had their own land, in Calamba the position of the inquilinos in the mid-1880s worsened when squeezed by rising rent and plummeting world sugar prices caused by the bounty system that subsidised beet sugar producers in Germany and France. ${ }^{75}$

In November 1884 Paciano wrote José Rizal about their financial difficulties: they had lost over 3,000 pesos on their capital and were in debt for 4,000 pesos for 'the new machine' (la nueva máquina). ${ }^{76}$ Neither the creditor nor this machine was specified. What is certain is that, by this time in the late nineteenth century, there were still no steam-powered sugar mills (with metal grinders that were comparatively more

70 MacMicking, Recollections, pp. 281-2. See also Quirino, The history of the Philippine sugar industry, p. 30; Roth, The friar estates, p. 138.

71 See Larkin, The Pampangans, p. 81.

72 Larkin, Sugar, p. 48.

73 Legarda, After the galleons, pp. 255-89.

74 Ibid., p. 282.

75 Napoleon Bonaparte established the beet sugar industry in 1811, instigated by the British blockade of Europe and the Haitian revolution against Napoleon's brother-in-law, which curtailed the importation of cane sugar. By 1837 France had become the world's largest beet sugar producer, but Germany overtook it by 1880 . Beet sugar was protected by bounties or subsidies to producers based on export production. In January 1885 Paciano wrote to younger brother José Rizal asking for accurate information on the state of beet sugar production in Europe in order to assess the threat it posed to Philippine sugar. The 'real misfortune', Paciano opined, was the country's 'great distance from the grand centres of commerce'. Biblioteca Nacional de Filipinas, Epistolario Rizalino, vol. 1: 1877-1887 (Manila: Bureau of Printing, 1930), pp. 133-4.

76 Ibid., p. 128. 
efficient in extracting juice from the cane) in Calamba. According to the Dominican hacienda administrator, Paciano's aborted plan for sugar production included the acquisition of steam-powered mills, with funds to be sourced from Paciano's father and the Chinese financier (and future financier of the revolution) Telesforo Chuidian. ${ }^{77}$ If this account is accurate, Paciano had become alert to the need to improve milling technology, probably to navigate the crisis in the sugar market, although he did not have the necessary capital to do so. Certainly the Dominican owners had realised this. Beginning with Rizal's family, the series of evictions of inquilinos from the Hacienda de Calamba from 1888 to 1891 caused their replacement by Spanish inquilinos, who were given loans by the Dominicans to install steam-driven mills; only then was investment made in mill technology in the hope of selling sugar directly to British Hong Kong without consorting with Chinese middlemen. ${ }^{78}$

Unlike the constraints on investments in Calamba, Negros experienced a period of enormous risk taking. Many haciendas relied on the crude carabao-driven mill (molino de sangre) for making muscovado sugar, but there were also many that had invested in steam mills, with capital borrowed from foreign merchant houses in Iloilo. ${ }^{79}$ Apart from the Basque-owned Ynchausti y Compañía that loaned to a number of hacenderos in Negros, the big merchant houses in Iloilo by the $1880 \mathrm{~s}$ were composed of four British entities (Smith-Bell, Ker, W.F. Stevenson, Macleod) and one American (Peele-Hubbell) and one Swiss (F. Luchsinger) company. ${ }^{80}$ With funds obtained from Western banks and big private investors, ${ }^{81}$ these foreign merchant houses provided hacenderos credit to purchase machinery.

To enhance their profits, these firms had a direct interest in improving milling technology, a practice essayed by Nicholas Loney. ${ }^{82}$ Loney set up his own merchant house, Loney and Ker. Although he died in 1869 in Iloilo at the age of 41, Loney

added something new to the operations of foreign entrepreneurs, offering machinery to sugar planters payable out of the increased profits possible from the use of modern equipment. In this way, he was able to overcome the natural conservatism of rural folk, and when the first machines proved profitable there was a rush to acquire them. ${ }^{83}$

77 Arcilla, 'Documents', p. 582.

78 Roth, The friar estates, p. 138.

79 Aguilar, Clash of spirits, p. 107.

80 Ibid., p. 119. Legarda explains the bankruptcy of the American firms Russell-Sturgis in 1876 and Peele-Hubbell in 1887, the former for a host of reasons including mismanagement, the latter because of the sugar crisis. British merchant houses, which survived the 1880 s crisis, were under the overall control of the parent company in Britain, with the resident partner in Manila having signing powers only. British companies were engaged in both imports and exports, while the American firms dealt in exports only (Legarda, After the galleons, pp. 320-26).

81 Legarda, After the galleons, pp. 275-9; Larkin, Sugar, p. 71. The Dominican order, along with the Augustinians, Franciscans, and Recollects, was known to have invested in Russell and Sturgis, but there is no information in the case of other foreign merchant houses (Legarda, After the galleons, p. 277). Apparently enterprising, the Dominicans loaned funds to the Spanish inquilinos after the 1891 deportation, incorporated the Hacienda de Calamba, and renamed it in English as the 'Philippine Sugar Estates Development Corporation' (Roth, The friar estates, pp. 151-2). Toward the end of the century the Dominicans had picked up a few lessons from the foreign merchant houses. 82 Aguilar, Clash of spirits, p. 107.

83 Legarda, After the galleons, p. 310. Loney's trading house folded up in 1875; Larkin, Sugar, p. 71. 
Given relatively easy access to capital, by the late 1880s there were in Negros 200 steam-powered mills and 30 hydraulic mills, in addition to 500 carabao-powered iron mills. ${ }^{84}$ Evidently the Negros hacenderos' access to capital enabled them to invest in new machinery in a way that was not possible in Calamba.

Despite its belated start, ultimately Negros, with its openness to outside ideas, produced a higher-quality sugar than Luzon, enabling it to coast along the sugar crisis of the mid-1880s. Thus the crisis had a dramatic impact on Calamba (and Pampanga), but not in Negros. ${ }^{85}$ Visayas sugar, with its high sucrose content, remained saleable in the world market, particularly in the United States and Britain. The export of Visayas sugar rose till the end of the century, when Western consumer tastes shifted markedly to refined white sugar and even the better-grade muscovado sugar could no longer compete with high-quality beet sugar. ${ }^{86}$ In contrast, Luzon sugar was of an inferior quality - Pampanga sugar was even laced with molasses - and it needed further processing in Manila prior to shipment abroad. ${ }^{87}$ As such, the demand for Luzon sugar in the United States and Europe declined precipitously, leaving it to be absorbed mainly by the low-priced China-Japan market. ${ }^{88}$

Apart from the funds to purchase machinery, foreign merchant houses regularly extended crop loans or cash advances to Negros hacenderos to secure a definite supply of exportable produce. Newer Western and Chinese companies insinuated themselves in the provisioning of crop loans, 'but they did not entirely replace the early pioneer lenders; nor did the alternate sources of credit provide capital at the same favourable rates'. ${ }^{89}$ One Chinese firm, Lim Ponzo and Company, was based in Iloilo but had a store in Victorias and a warehouse in Silay to facilitate the extension of crop loans and the acquisition of sugar; its practices sought to curtail the options of its debtors. ${ }^{90}$

Negros's sugar economy, which was minuscule in the 1850s and conceivably behind that of Calamba, began to grow in earnest in the 1860s and 1870s, directly tied to the Iloilo-based foreign merchants. In this sense, these companies directly mediated Negros's articulation to the global sugar market - they provided loans to Negros hacenderos, sold them newer technology, acquired their produce, and sold the sugar to foreign buyers. Even though there were some Chinese sugar traders, what prevailed in Negros was not the usual Anglo-Chinese nexus.

In Calamba the sugar producers' linkage to the world sugar market was mediated by Chinese middlemen, who in turn were instrumental in passing on the exportable

84 Aguilar, Clash of spirits, p. 117. For slightly different figures, cf. Larkin, Sugar, pp. 61, 83.

85 Bosma et al. have argued that '[a]lthough it appeared an epoch-marking calamity to those affected by it, in retrospect, the "sugar crisis" of the mid-1880s was grossly inflated in terms of its impact. In fact, it was preceded by a fall in the world price of sugar for the previous two decades and simply worsened in the 1880s'. Ulbe Bosma, Juan Giusti-Cordero, and G. Roger Knight, 'Sugarlandia revisited: Sugar and colonialism in Asia and the Americas, 1800 to 1940, an introduction', in Bosma et al., Sugarlandia revisited, pp. 14-15. This panoptic survey is insensitive to the micro world of Calamba and its political ramifications for Philippine history.

86 Larkin, Sugar, pp. 54-6.

87 Ibid., p. 51.

88 Ibid.; Aguilar, Clash of spirits, pp. 121-4.

89 Larkin, Sugar, p. 71.

90 Ibid., pp. 71-2. 
sugar to the foreign merchant houses in Manila. The Chinese middlemen in Luzon would appear to not have been in the position to improve the extant milling technology. Neither did the Manila-based foreign merchant houses show interest in spreading better mills to Calamba, ${ }^{91}$ apparently because, as Loney explained in 1861, these merchants were 'opposed' to selling machinery on terms other than cash 'particularly to planters in distant provinces, with the extent of whose means they are but imperfectly acquainted'. ${ }^{92}$ Some of these merchant houses in Manila also went bankrupt, particularly during the depressed market years. ${ }^{93}$ The overall effect of these various factors was to deprive Calamba of capital for investment in better milling facilities.

In short, the direct linkage to foreign merchant houses found in Negros was nonexistent in Calamba, spelling the difference in the resulting economic formation in these two locations and their capacity to overcome the vicissitudes of the market.

\section{The plural society of Negros}

In stark contrast to Negros, the Hacienda de Calamba was an enclosed world, an enclave economy, and an ethnically stratified society. The Dominican order and the members of this religious congregation managing it were clearly perched on top of this social formation. Beneath them was a class of wealthy inquilinos who were predominantly Chinese mestizos. At the base of this social pyramid was the mass of native peasant sharecroppers. There were no other foreign elements on the friar estate, even if its sugar produce was directly intended for the world market. Until the eviction of inquilinos in 1891, Calamba's colonial class structure had remained essentially the same as it was in the early nineteenth century. ${ }^{94}$

Negros, however, was a completely different world from Calamba. Beginning in the late 1850s the allure of wealth from sugar production enticed several migration streams to Negros. From across the Guimaras Strait came Chinese mestizos, mainly from the Iloilo districts of Molo and Jaro, who ventured to become sugar hacenderos in Negros, forming the kernel of the biggest segment of the fledgling sugar planter class. McCoy has shown a remarkable connection between these Negros hacenderos and Iloilo's pre-1855 elite. Among the family names of former gobernadorcillos of

91 However, through a Spanish dealer, the use of steam mills manufactured in England reached Pampanga in 1858; by 1870 there were 31 such machines and by 1899 the number had risen to 177 . Larkin states that José Puig, 'a dealer in steam mills as well as land', who engaged in 'buying, selling, and leasing of machinery', could have 'constituted a strong factor in the adoption of steam milling by farmers throughout the province' (Larkin, The Pampangans, pp. 70, 77-8). Apparently a Spanish entrepreneur brokered the distribution of these machines to sugar planters in Pampanga, thus obviating the need for foreign merchant houses to transact directly with the sugar hacenderos there, unlike in Negros. 92 Cited in Legarda, After the galleons, pp. 309-10.

93 As Larkin states (in Sugar, p. 53), 'Weak markets prevented recovery, especially in central Luzon; moreover, several old sources of credit to the industry had dried up by this time. The two American firms that had supplied so much cash and machinery [to Pampanga] in former years had gone bankrupt, Russell, Sturgis in 1876 and Peele, Hubbell in 1887, while a large British lender, Smith, Bell, faced deep financial trouble because of its inability to sell its overstock of sugar in New York'.

94 Population data for Calamba in 1891 showed 14,019 naturales (natives), 16 español peninsulars (peninsular Spaniards), and 13 mestizos de español (Spanish mestizos). No one was listed as mestizo de sangley (Chinese mestizo). Rhina Alvero Boncocan and Dwight David Diestro, Nineteenth century conditions and the revolution in the province of Laguna (Quezon City: Center for Integrative and Development Studies, University of the Philippines, 2002), p. 40. 
Molo that were found in Negros were those of Araneta, De la Rama, Locsing, Maravilla, Tiongco, and Yusay. In the case of former cabezas de barangay (village chiefs) in Molo, the list of family names in the roster of natives (naturales) found in Negros included Arroyo, Hechanova, Magalona, Maravilla, and Villanueva; those in the roster of mestizos included Araneta, Lacson, Montelibano, and Severino Yuson. ${ }^{95}$ Because the ethnic boundaries were malleable, there could be no strict demarcation between Chinese mestizos and naturales. In any event, the Negros hacenderos from Iloilo were largely of Chinese mestizo background.

Many of these Iloilo elites had been engaged in the native textile industry, but ethnic Chinese trading networks that distributed cotton goods and textiles brought into the country from Manchester and Glasgow by British merchant houses in Manila began to undercut the native industry. The direct importation of these goods into Iloilo did not become significant until the 1880s, but Chinese competition and attractive sugar prices compelled Iloilo's Chinese mestizos to abandon native textiles for a stab at sugar production in Negros. ${ }^{96}$

Also migrating from across Panay and nearby islands were countless ordinary peasants (mostly naturales), who were attracted to the exciting world of Negros either as hacienda hands or independent peasant cultivators. In 1861 Loney reported that Iloilo elites were settling down in Negros together with peasant families who would serve as their share tenants. ${ }^{97}$ Later, hacenderos themselves were said to go around the villages in Iloilo in search of hacienda hands. ${ }^{98}$ Some peasant families whose incomes were affected by the displacement of female labour that had been formerly engaged in textile weaving might have been predisposed to migrate to Negros. But most of the peasants who moved to Negros could well have stayed on in their places of origin, generally engaging in rice and other subsistence production. Evidently they were attracted to Negros, which appeared to offer fresh opportunities, both on as well as outside of the haciendas, seemingly beyond the reach of the colonial state. Despite the complex relationship between naturales and Chinese mestizos, ${ }^{99}$ they found themselves contending but also strategising with each other in Negros. ${ }^{100}$

Apart from the Iloilo connection, the sugar hacendero class was a diverse group in terms of origins, ethnicities ('races'), and economic strengths. Eschewing the mindset of setting themselves above Chinese mestizos and naturales, lay Spaniards of many stripes sought their fortunes in Negros, most becoming hacenderos. For their part, the Spanish Recollect friars' concern for their mission field moved them to support and participate in the sugar economy, but they did not dominate the scene unlike in the monastic estates in the Tagalog region. Also attracted to the sugar economy of Negros were Chinese and other Europeans. In time many other migrants would flock to

95 Alfred McCoy, 'Ylo-ilo: Factional conflict in a colonial economy, Iloilo Province, Philippines, 1937-1955' (PhD diss., Yale University, 1977), pp. 67-70.

96 Aguilar, Clash of spirits, pp. 97-9.

97 Ibid., pp. 127-8.

98 Ibid., p. 128.

99 Ibid., p. 80.

100 The blatant oppression of labour, along with paternalistic strategies, would be a phenomenon of the twentieth century when the sugar planter class consolidated its hegemony under US colonial patronage (ibid., pp. 189-228). 
Negros, including probably at least one Ottoman Syrian immigrant. ${ }^{101}$ As already mentioned, most of the large foreign merchant houses in Iloilo that were immersed in the Negros sugar economy were British, but there were also American, Swiss, Chinese, and Spanish interests. Some of these merchant concerns also had direct ownership of haciendas in Negros.

Unlike Calamba where the handful of blancos (whites), at least until the 1891 evictions, were primarily members of the Dominican order, Negros witnessed a rising number of Spanish peninsulars and creoles in the course of the nineteenth century. The number of blancos, including both types of Spaniards and other Europeans, rose from 13 in 1861 to 20 in 1866 to 60 by 1880 and to as many as 254 by 1888, along with 631 Chinese. ${ }^{102}$ The vast majority of Spaniards in Negros was involved in the sugar economy. This heavy engagement of Spaniards in agriculture was contrary to what had prevailed in most other parts of the Spanish Philippines since the days of the galleon trade. In fact, creoles were known to have disdained agriculture and commerce, which explained their heavy reliance on sinecures in the colonial bureaucracy.

Outside Negros, Spaniards in Cebu and Pampanga were engaged in agriculture but they did not reach the numbers seen in Negros. According to Michael Cullinane, quite a few Spaniards arrived in Cebu as early as the late 1860s, but more came in the 1870 s and 1880 s who engaged in sugar production, mainly in the Bogo-Medellin area (six peninsulars and one Spanish mestizo); Toledo (six peninsulars); Sibonga (two peninsulars); and Barili-Dumanjug (one peninsular and one creole). ${ }^{103}$ Pampanga registered a respectable number of Spaniards with ties to agriculture: twenty-seven out of the fifty-eight who resided in Pampanga in 18871888, except for one who owned over 3,300 ha, 'had landholdings no larger than those of the typical native owners of the province', which in any case they generally leased out rather than personally managed. ${ }^{104}$ In Pampanga these Spaniards 'played a minor economic role in the total economic scene', ${ }^{105}$ contrary to the case in Negros.

Data for Negros in 1888 indicated a clustering of blancos in eight towns, with the largest concentrations found on the eastern coast of the island: Bais (38), Dumaguete (31), and Tanjay (43). These aspiring sugar planters must have been latecomers in the

101 Juan Caram (Hanna Karam) owned the 50-ha Hacienda Montelibano in Isabela, Negros Occidental, although it is uncertain when he actually obtained possession of this hacienda. Caram arrived in the Philippines around 1885, dedicated himself to trade, and by 1890 he and his wife and three children were living in Iloilo. William Clarence-Smith (email to the author, 16 Nov. 2015) very kindly shared this information with me. The court case involving Caram's descendants indicates that Caram passed away in 1939 and that 'during their lifetime' he and his spouse Maria Gacibe owned this hacienda in the interior municipality of Isabela in central Negros. 'Miguel Caram and Fermin G. Caram, petitioners, vs. The Honourable Court of Appeals and Rosario Montilla, respondents', G. R. No. L-7820 (Supreme Court, Republic of the Philippines, 1957), The LAWPHIL Project, http://www.lawphil. net/judjuris/juri1957/apr1957/gr_l-7820_1957.html (accessed 5 Nov. 2015). For an overview of migrants from the Ottoman Empire to the Philippines, see William Clarence-Smith, 'Middle Eastern migrants in the Philippines: Entrepreneurs and cultural brokers', Asian Journal of Social Science 32, 3 (2004): 425-57.

102 Aguilar, Clash of spirits, p. 101.

103 Michael Cullinane, email to the author, 19 Nov. 2015.

104 Larkin, The Pampangans, p. 77.

105 Ibid. 
game of sugar for apparently they could no longer find land on the west coast, which was directly across the Iloilo port. ${ }^{106}$ Earlier Spanish migrations would account for the sizeable Spanish presence on the west coast: Bacolod (12), La Carlota (20), Jimamaylan (11), Minuluan (20), and Pontevedra (22). ${ }^{107}$ Given the preexisting animosities between peninsulars and creoles, ${ }^{108}$ the observation made by Recollect historian Fr. Angel Martinez Cuesta about a pattern of ethnic concentration is not unexpected. ${ }^{109}$ For instance, La Carlota was a major place of congregation for peninsulars, while Jimamaylan attracted creoles as a group. As in most cases of economic migration, migrant networks formed around kin and ethnic lines facilitated the process of movement to and settlement in different locations in Negros. ${ }^{110}$

La Carlota was known as one of the locations in Negros where Basques, along with Ynchausti y Compañía, owned a number of haciendas. ${ }^{111}$ The census data available in the National Archives of the Philippines show a total of 24 peninsulars (20 males, 4 females) in La Carlota. ${ }^{112}$ They were found in about a dozen (or 30 per cent) out of the thirty-nine or so haciendas in this town. But even among the peninsular Basques there was some inequality. The combined information from Marciano De Borja and the census tables in the national archives indicate that in La Carlota Julian Uriarte owned two haciendas: the 300-hectare Hacienda Fe and the 100-hectare Hacienda Vizcaya. The smaller Basque-owned haciendas measured 150 ha only: Hacienda San Vicente owned by Manuel Crame and Hacienda Pilar owned by Maria Candela. ${ }^{113}$

As in John Furnivall's (1948) classic notion of the plural society, ${ }^{114}$ the market brought these Spanish hacenderos to live side-by-side, as it were, with native hacenderos, who were mostly Chinese mestizos by descent. In La Carlota the Spanish hacenderos also lived side-by-side with two Chinese hacienda owners, identifiable despite their Hispanised names because these were preceded by 'Chino': Martin Cilis, who owned 150 ha, and Vicente Ferer, who owned 10 ha. In the town centres were found a number of Chinese traders, such as the fifty-five Chinese men enumerated in La Carlota's town centre, but they did not mediate the export of sugar in the way Chinese middlemen did in Calamba.

106 Aguilar, Clash of spirits, p. 246.

107 Ibid.

108 Ibid., p. 101.

109 Martinez Cuesta, History of Negros, p. 376.

110 Cf. Larkin, Sugar, pp. 64-5.

111 Marciano R. De Borja, Basques in the Philippines (Reno: University of Nevada Press, 2005), pp. 146-7.

112 'Estado del número ... Pueblo de La Carlota, 31 de Diciembre 1896', Estadística, Negros Occidental. Part I, National Archives of the Philippines.

113 In the wake of the Carlist Wars and with the loss of Spanish America (except for Cuba and Puerto Rico) limiting their options, Basques migrated to the Philippines in sizeable numbers, perhaps about 2,000 in the course of the nineteenth century. This migration stream included Bizkaian seafarers; Navarrese traders and farmers who planted abaca, coconut, and sugarcane; Gipuzkoans who went to Mindanao or who engaged in trade, such as José Joaquin de Ynchausti, whose later partners were Navarrese, such as Elizalde; and Arabans who were mainly in government service and later set up their own businesses, such as the Ayalas. A handful of French Basques were established in Manila (De Borja, Basques in the Philippines, pp. 84-97).

114 John S. Furnivall, Colonial policy and practice: A comparative study of Burma and Netherlands India (New York: New York University Press, 1948). 
The mixing of all these diverse social categories, as previously argued, ${ }^{115}$ transformed Negros into a giant colonial cockpit where members of these social categories intersected and intermingled, combined but also segregated themselves. Negros was a place for contesting but also asserting as well as amending and reinscribing the social classification schemes of colonial society. Money flowed in the cockpit, but so did other forms of social interactions, made possible by participation in a common gambit. The church and social functions, not to mention the gambling table, were arenas for interethnic interactions. Thus, unlike Furnivall's plural society, which assumed that the different social categories remained separate and interacted only in the marketplace, in Negros their mixing went beyond the market.

At midcentury MacMicking had observed that

The intercourse between the Spaniards and many of the foreigners residing at Manilla is not very great, as the British here, as everywhere else, appear to prefer associating with their own countrymen to frequenting the houses of their Spanish friends .... ${ }^{116}$

He had also noticed that

There is very little, or almost none, of that mutual confidence existing between them [Spaniards] which exists between British merchants, and which is so necessary in large transactions, or in carrying on an extensive business, as they do. ${ }^{117}$

These and other interethnic prejudices alluded to above, which prevailed across all social groups that ventured into the Negros-Iloilo sugar economy, were gradually eroded as individuals began to move beyond their own ethnic boundaries and entered into 'large transactions' and carried on 'extensive business'. But the 'mutual confidence' within and across social groups was not built overnight and not always successfully.

In the mid-1860s Remigio Molto, the Intendant General of the Visayas, ${ }^{118}$ described the Spaniards who had ventured into Negros as poor retirees who had served either in the Spanish military or civilian bureaucracy but whose meagre salaries did not enable them to accumulate the capital needed for sugar production. Molto accused the foreign merchant houses of exploiting the Spaniards' 'misfortune' by charging high interest rates, forcing them to purchase machinery, and requiring them to sell their sugar at lower than the prevailing market prices. Given this supposed stranglehold, the governor alleged that Spaniards were desperately selling out their haciendas, raising the spectre of 'foreigners' owning the haciendas of Negros. ${ }^{119}$ Molto's memorandum suggested that the poorly financed Spanish hacenderos, at least initially, did not only distrust Iloilo's foreign merchant houses but also lacked comprehension of the sugar industry. Molto's complaint was thus in accord

115 Aguilar, Clash of spirits, pp. 106-10.

116 MacMicking, Recollections, p. 78.

117 Ibid., p. 90.

118 'Sobre los medios de colonizar la Ysla de Negros', Regimio Molto to Gobernador Superior Civil, Cebu, 13 Aug. 1864 and 17 Aug. 1865, Legajo 447, Expediente No. 15, Archivo Historico Nacional, Madrid. Molto wrote as head of the Gobierno Intendencia de la Provincia de Visayas (Intendancy Government of the Province of the Visayas).

119 Aguilar, Clash of spirits, p. 118. 
with the deep suspicion that, since the early 1800s, Spaniards had harboured against foreign merchants who they pictured as economic saboteurs, heretics, and political agitators. ${ }^{120}$ Contrary to Molto's doomsday scenario of the 1860 s, the number of Spanish hacenderos in Negros would rise until the end of the century. ${ }^{121}$

While the market brought this plural society together, the society itself was not glued together by a common 'social will', as Furnivall put it. Not surprisingly, sugar production concomitantly occasioned the clash of interests, as in the contest for land. On 12 August 1876 eleven peninsulars based in La Carlota (including Lucas Rubin and Manuel Pacheco) petitioned the governor-general to nullify the usufruct claims to land of the controversial Chinese mestizo from Jaro, Iloilo, Teodoro Benedicto, who they alleged acquired lands fraudulently. They also accused Benedicto of diverting the flow of a river, which deprived their haciendas of irrigation water. Moreover, the petitioners alleged that the creole Bonifacio Montilla of Bago had similarly usurped large tracts of land in Bago. However, a slightly earlier petition dated 1 August 1876 signed by fifty-five residents of barrio Borja in Pontevedra accused the Spaniards of similarly usurping land. Another petition dated 27 August 1876 signed by ten leading natives of Pontevedra accused Lucas Rubin of constructing a canal that diverted the waters of the local river. Amid this tit-for-tat Benedicto and his peninsular foes were evidently seeking to acquire the same parcels of land, with Benedicto gaining the upper hand through various extralegal and illegal means, to the detriment of countless peasants who were thereby dispossessed of land. ${ }^{122}$

In any event, in the second half of the nineteenth century, Negros was an open, if profoundly unequal, society that was directly linked to the world market through foreign merchants. There a classic plural society emerged, with peninsulars - Basques especially - and a select group of Recollect friars, creoles and Spanish mestizos, Chinese mestizos, naturales, Chinese traders and a few Chinese landowners, a handful of other Europeans and other immigrants seeking their fortunes in Negros, brought together by the market, but also competing with each other on issues related to but exceeding the market. In doing so, they effectively sidelined the state in Negros.

\section{Resistance against the colonial state}

According to Paciano Rizal, the controversy in Calamba - which started in 1883 or a couple years before sugar prices declined in 1885 - initially centred on rental payments and the hacienda administration's arbitrary practice of not issuing the usual receipts. ${ }^{123}$ The civil authorities in Manila were brought into the picture when they began to suspect that the state was being shortchanged in regard to the diezmos prediales (tithes on land), an impost which 'consisted of one-tenth of the liquid value realised from the products of farm lands, particularly large estates'. ${ }^{124}$ The diezmos were added to the rent for eventual remittance by the Dominicans to

120 Ibid., pp. 15-22.

121 Amid the crisis of the mid-1880s Antonio Tovar, governor of Negros, censured the foreign merchant houses for being casas acaparadoras (monopoly houses), acquiring Negros sugar on grossly unfair terms and leaving sugar planters with 'frustrated dreams' (ibid., p. 119).

122 Ibid., pp. 110-13.

123 Biblioteca Nacional de Filipinas, Epistolario Rizalino, p. 91.

124 Eliodoro Robles, The Philippines in the nineteenth century (Quezon City: Malaya, 1969), p. 271. 
the colonial state under the conditions of the Patronato Real. ${ }^{125}$ The amount of the diezmos collected from the inquilinos was rising but payment to the treasury was declining, prompting the investigation in 1887 to determine if the Dominicans had complied with their obligation. ${ }^{126}$

It should be made clear that, although the Hacienda de Calamba might have sought to minimise its payments to the colonial state, its very existence depended on being an appendage of the state. In fact, because the monastic estates were amassing considerable wealth during the second half of the nineteenth century, the religious orders extended huge loans to the financially strapped colonial treasury at a low interest rate, with the treasury amortising the loans by excusing the remittance of the diezmos for a specified number of years. ${ }^{127}$ The friar haciendas and the colonial treasury were thus engaged in mutual accommodation. Like other friar estates, Calamba was a state-sanctioned enclave economy.

During Rizal's visit to the homeland from August 1887 to February 1888, Rizal inspired, if not aided, the inquilinos in presenting their grievances against the Calamba hacienda administration. They alleged the illegal extension of the hacienda's boundaries that usurped privately cleared land and rental fees that were excessive and arbitrarily raised; they demanded formal contracts or the sale of the land to whoever had cleared them. ${ }^{128}$ But the civil authorities shirked from a possible confrontation with the Dominicans, leaving the people of Calamba high and dry. ${ }^{129}$ Several inquilinos began to withhold their rental payments, which continued even after Rizal's departure, prompting the Dominicans to go to court to secure eviction orders. Rizal eventually appealed the case to the Supreme Court in Madrid, but before any verdict could be issued in October 1891 Valeriano Weyler as governor-general stepped in to bolster the Dominicans by burning houses and banishing the recalcitrant inquilinos, including Rizal's parents, brother, and sisters. ${ }^{130}$

This well-known episode of Philippine history underscores that at several levels the Hacienda de Calamba represented and imbricated colonial state interests. Pressed by the world sugar market and the hacienda, Rizal and other inquilinos saw the dispute as a way of challenging the colonial state and putting to the test Spain's policy of colonial assimilation. For his part Weyler understood the conflict as a larger struggle for ascendancy. He saw the recalcitrance as a prelude to a

125 Roth explains that the diezmo predial was originally a tithe paid directly to the Catholic Church in medieval Spain, but under the Patronato Real the Crown obtained the right to administer this fund to support missionary activities. In Las Islas Filipinas only Spanish lay and religious landowners paid this land tax, and natives were exempt unless they were tenants of these landowners. This tax was bitterly resented by Spanish landowners, who felt discriminated against because natives did not have to pay it (Roth, The friar estates, pp. 144-5). In 1866 the Royal Economic Society recommended the suppression of the diezmos prediales, but to no avail (Robles, The Philippines, p. 212).

126 Roth, The friar estates, p. 145.

127 Ibid., p. 95.

128 Schumacher, The Propaganda Movement, p. 246. Another irritant was the collection of rent for house lots, which became the responsibility of the leaseholders. As the inquilinos took on more of such responsibilities, 'they became less willing to suffer rent increases and the threat of eviction' (Roth, The friar estates, p. 151).

129 José Rizal, 'La verdad para todos / The truth for everybody', La Solidaridad, vol. 1: 1889, trans. Guadalupe Fores-Ganzon (Pasig City: Fundación Santiago, 1996), pp. 168-77.

130 Guerrero, The first Filipino, pp. 195-203. 
campaign for independence and sought to suppress it. This enclosed world of Calamba, along with the troubles it brought to his family, was encapsulated in the subplot surrounding Cabesang Tales in Rizal's El filibusterismo, which resulted in the murder of the friar in charge of rents and of the new tenant that took over Tales's land. Tales becomes the fearsome bandit chief Matanglawin. In no small measure stoked by Calamba, Rizal's despair brought forth the anarchism that, as Benedict Anderson has shown, suffuses his second novel. ${ }^{131}$

In contrast, there was no single Spanish colonial institution that became the concerted target of native resistance in Negros, where agricultural, economic, and technological conditions allowed the haciendas to weather the crisis of the 1880s. Quite routinely and in disparate ways the sugar hacenderos of Negros engaged in sidestepping, if not directly undermining, the colonial state. Hacenderos, as already mentioned, utilised various extralegal means to obtain and expand their landholdings, running to the state only to serve as umpire in their intramurals over land. When, in the late 1880s, a new tax on urban property and industrial as well as commercial income was imposed, without the detested diezmos being abolished especially for Spanish taxpayers, the hacenderos responded by devising schemes to reduce or even avoid paying the tax. Some were caught but eventually absolved, suggesting that anti-state strategies paid off. ${ }^{132}$

Given the hacenderos' lack of class dominance, the control of labour was a major issue for them. In the 1880s the hacenderos sought Spanish Manila's intervention in regulating labour, but the authorities demurred and shirked from taking action. ${ }^{133}$ Hacenderos also engaged in stiff competition among themselves to obtain labour, sometimes resorting to the hiring of undocumented migrants (indocumentados) as well as fugitives. Highlighting contradictions within the Spanish ruling elite, some Recollect friars connived with Spanish hacenderos in contravening state regulations, as the curate of Cabancalan did in helping the peninsular Rafael Alvarez employ illegal labour. The local Guardia Civil could only decry such 'very frequent' acts of defiance but was unable to do much about it. ${ }^{134}$

Despite the colonial state's ban on gambling (juegos prohibidos), Negros cultivated a freewheeling atmosphere that institutionalised gambling, especially cockfighting, as an illicit labour-enticing strategy on these haciendas. ${ }^{135}$ For their part, countless peasants from neighbouring islands migrated to Negros, often illegally, to locate themselves far from the reach of the state; whenever possible, they demanded cash advances before agreeing to work, only for many to abscond and unravel the fledgling hacenderos' incomplete class dominance. ${ }^{136}$

For all intents and purposes, the colonial state was irrelevant in 'unruly' Negros, where every hacienda, isolated by poor transportation infrastructure, sought to be its own power centre. Negros disrupted the established church-plaza complex found in

131 Benedict Anderson, Under three flags: Anarchism and the anti-colonial imagination (Pasig City: Anvil, 2006).

132 Aguilar, Clash of spirits, pp. 119-20.

133 Ibid., pp. 135-8.

134 Ibid., pp. $138-40$.

135 Ibid., pp. 146-8.

136 Ibid., pp. 126-30. 
municipal centres in other parts of the Spanish Philippines. Whereas social prestige was normally measured by proximity to the local representation of tangible Spanish power, several hacenderos in Negros erected their well-built houses on their hacienda premises far from the town centre. The physical landscape encoded the social gamble as well as the shunning of colonial power. ${ }^{137}$ In Negros, one could say, the native found a form of 'liberty' (libertad) that Rizal, in his essay on indolence, prescribed as necessary for the native's 'adventurous spirit' (su espíritu aventurero) to have free rein and flourish. ${ }^{138}$

Moreover, the Spanish colonial state was far from being a 'developmental' state. Bereft of capital and technical expertise, it could not lend assistance to the sugar hacenderos, yet saw the foreign merchant houses as exerting a stranglehold on these planters. The hacenderos were probably cognisant of the limitations but also of the palpable benefits of linking up with the merchant houses. But the colonial state did not understand the exigencies of Negros's sugar economy. Neither did it show an appreciation for the international sugar market and the role of the foreign merchant houses in Iloilo. Adding insult to injury was the action of Madrid, amid the sugar crisis in December 1884, to conclude negotiations on a treaty that granted Cuban and Puerto Rican sugar, but not Philippine sugar, duty-free access to the lucrative US market, by then the major consumer of Philippine sugar. In the Visayas the news was greeted with disbelief. The hobbling Spanish empire would try to remedy the situation, but its policies remained haphazard and inconsistent. ${ }^{139}$ As it had done since the midcentury, Negros had to fend for itself.

Under changed historical conditions, that is, in the wake of the downfall of Spanish power in the island in November 1898 and the presence of a US expeditionary force in Iloilo, the planters did not hesitate to form a government for Negros. Still these hacenderos vacillated between self-rule for the island and inclusion in a Philippine state with headquarters in Malolos - an outgrowth of decades of manoeuvring against a central state. ${ }^{140}$

\section{Conclusion}

Arguably sugar planters in Negros waged a concerted evasion of the colonial state, at least while the islands remained under Spanish suzerainty. An island that until the 1850s was virtually terra incognita, Negros attracted migrants from adjacent islands who were lured by the market to establish sugar haciendas based mainly on sharecropping, but with capital and technology provided by foreign merchant houses. The conditions of sugar production in Negros enabled it to weather the sugar crisis of the 1880s. The multiethnic planter class of Negros manoeuvred its way to prosperity, with the blessings of Recollect friars who did not constitute a rentier class. In contrast, sugar planters in Calamba relied on local capital and backward technology. Together with their sharecroppers, these planters were squarely under a religious corporation,

137 Ibid., pp. 149-53.

138 Rizal, 'Sobre la indolencia', pp. 416, 420.

139 Aguilar, Clash of spirits, pp. 120-25.

140 Filomeno Aguilar Jr., 'The Republic of Negros', Philippine Studies 48, 4 (2000): 26-52. On 4 March 1899 the people of Bacolod welcomed the US occupation force, but the Negros sugar elites continued to hedge their bets (ibid., pp. 31-2). 
the Dominican order, which pursued its own interests that were inextricably bound up with the colonial state. A relatively strong state presence but weak market linkage defined conditions in Calamba, witnessing the rental squeeze of sugar growers in the 1880 s, and resulting in a native elite strategy that was intentionally political. Paradoxically Negros, where the state was riddled with contradictions, thrived in its anarchic way as many seized opportunities to maximise their individual economic interests, each one undermining the state amid the island's direct articulation with the global economy, a nexus that existed only indirectly in Calamba whose closed economy hindered its advance and was the cause of its undoing.

One wonders how Rizal would have composed his essay on indolence had he been truly cognisant of the world of sugar haciendas on the island of Negros. One wonders further what the figuration of his anticolonial imagination might have been had his family produced sugar not in Calamba but in Negros, where the rich person could brush aside the vexations that haunted Calamba. 